\title{
Analyzing Relationships Among Activities for Teacher Development, Teaching Beliefs, Efficacy and Teaching Behaviors of Elementary School English Teachers in Taiwan
}

\author{
Ping-Huang Sheu ${ }^{1}$ \\ ${ }^{1}$ Department of Children English Education, National Taipei University of Education, Taipei, Taiwan \\ Correspondence: Ping-Huang Sheu, Department of Children English Education, National Taipei University of \\ Education, Taipei, 10671, Taiwan. Tel: 886-2-2732-1104 \#55136. E-mail: samsheu@tea.ntue.edu.tw
}

Received: July 4, 2019

Accepted: July 25, 2019

Online Published: August 19, 2019

doi:10.5430/irhe.v4n3p1

URL: https://doi.org/10.5430/irhe.v4n3p1

\begin{abstract}
The purpose of this study is to evaluate elementary school English teachers' perspectives on the relationship of activities for teacher development, teaching beliefs, efficacy and behaviors regarding teaching English. This study intends to reveal the influential interconnection of the four variables by running regression analysis. A total of 197 elementary school English teachers in Taipei city participated in this study. The data was collected through a four-point scale questionnaire and the results indicated the path of activities for teacher development and teaching beliefs, and teaching beliefs and teaching behaviors respectively was significant. Teachers' engagement in professional development is crucial, and the educational authority is strongly recommended to take action on this issue.
\end{abstract}

Keywords: activities for teacher development, teaching beliefs, efficacy, teaching behaviors

\section{Introduction}

In respect that English language plays a decisive role in international trade and education around the world, English becomes an indispensable subject at all school levels in Asia especially, and the effectiveness of teaching and learning English depends heavily on English teachers, who appear to be pivotal in implementing English teaching programs appropriately and successfully (Luke \& McArdle, 2009). In other words, an English language teacher needs to have a good deal of knowledge of many factors that affect their teaching and students' learning, and of skills to design and carry out lessons effectively in the classroom. In order to do so, one has to not only maintain her/his knowledge and skills professionally, but also keep abreast with the rapidly evolving field of English language teaching (Bailey, Curtis \& Nunan, 2002). This has rendered professional development urgent for teachers so that they can keep updated with the changes and innovation in their field, especially for those who are largely influenced by traditional models of teaching, like that of Taiwan (Lau, 2006); and more importantly, such participations are deemed to have profound effects on teachers themselves and their teaching. In this respect, the need to develop professionally as English language teachers necessitates an active engagement in the activities for teacher development for the purpose of self-development (Karaaslan, 2003). Previous research has demonstrated the value of such active involvements on teachers themselves, including an interest in lifelong learning, a sense of moral obligation, a felt need to enhance teaching skills, an institutional requirement, and/or for career advancement (Golding \& Gray, 2006; Jasper, 2006; Kerka, 2003; Muijs \& Harris, 2003).

As being in the frontline of teaching situations, what teachers know about English teaching influences the way in which how English is taught in the classroom, and then, has an impact on their teaching behaviors. That is, beliefs on the nature of teaching, how students learn a language, and what content and strategies should be used have strong emotional and evaluative elements of shaping teachers' perspective, ideas, judgments, and values before, during and after teaching (Cabaroglu \& Roberts, 2000; Tercanlioglu, 2001; Thomas \& Pedersen, 2001). Consequently, teachers' beliefs stimulate inner incentive which serves as a dominant force in promoting the quality of their teaching practice, and then would have the best opportunity to close the gaps in students' learning and achievement (Dörnyei, 2001; Dörnyei \& Clèment, 2002; Ushioda, 2008; Wesely, 2009). Likewise, several previous studies (Jacobs \& Farrell, 2001; Hayes, 2000) have also demonstrated that teachers' professional development can impact positively on teaching 
processes and outcomes. Poulson, Avramidis, Fox, Medwell and Wray (2001) express that an interconnection exists between a teacher's beliefs and his or her teaching practices; while beliefs drive performance, teaching practices and experience have the power to change or supplement one's beliefs in return, and vice versa. Also, Stipek, Givvin, Salmon and MacGyvers (2001) illustrate that certain compatibilities exist between teachers' beliefs and their teaching practices in the classroom. Several study findings have indicated that beliefs are the main driving force for activities teachers perform with their students inside the classroom, and are also the most influential factor in teaching and learning processes (Pajares, 1992; Richardson, 2003; Woolfolk, Davis \& Pape, 2006). Thus, positive relation between teachers' teaching beliefs and their behaviors is said to be the strong predictor of their students' learning.

Furthermore, in EFL contexts, using English in classrooms is necessary and often is the only opportunity for students to gain exposure to the target language (Yashima, 2002). In this sense, their teaching efficacy evolves from self-concept, which can be defined as the sum of a teacher's perception of themselves (Cayci, 2011), and directly affects their teaching plans and behaviors in English lessons (Bandura, 2012). There is no doubt that designing and implementing a lesson should be systemized in order to achieve the desired teaching outcomes. This requires familiarizing one's self with his or her own knowledge and ability, which were formed in them from the time they started learning early in their lives up until the end of their career training courses, whether in college or during their teaching practice (Philippou \& Christou, 1998). Hence, teachers' behaviors are directed through what they believe they can do and what they have to be taught about English teaching and learning; that is, the performance of effective teaching practices is dependent upon the connection of their beliefs and efficacy. As Borich (1999) describes, both beliefs and efficacy can be seen as a direct result of the teachers' preparation programs or professional development with the focus on decision-making which is concerned with the course design and teaching practices.

It should be pointed out that the city's advisory team in Taipei organizes regularly different activities for teacher development covering various topics or issues related to the current English teaching situation, such as seminars, conferences, training sessions, and so on. Moreover, elementary school English teachers are asked to include some means of professional development in teaching practices, including peer reflection, peer teaching, observation, supervision, teaching journals, in-service training, short-term courses, mentoring, etc. All these measures intend to tackle such issues as what are the current trend of teaching approaches, methods and techniques, who and what is being taught and developed, and, most importantly, in whose interests (David, Olwen, Janis, Mary \& Anne, 2003). Expectantly, if teachers lean toward perceiving their teaching ability in accordance to what beliefs and knowledge they possess, they are more likely to adopt new approaches and skills in their teaching practices (Mitchell \& Myles, 2004). Several previous studies (Fullan \& Hargreaves, 2002; Lau, 2006; Shang, 2010) have demonstrated that activities for teacher development can impact positively on teaching processes and outcomes.

Considering the points laid out above, this study aims to inquire into the complex relationship between activities for teacher development, teachers' teaching beliefs, efficacy and teaching practices. First, this study examines whether activities for teacher development are directly related to teachers' teaching beliefs, efficacy and their teaching practices. The goal is to better understand the effects of the activities on links between beliefs, efficacy and practices. Ultimately, we hope to identify the activities for teacher development that will make the positive prediction about these three factors. Additionally, the correlation and the predictive power of teachers' teaching beliefs on teachers' efficacy and teaching practices are still unclear. In this regard, the present study intends to shed light on the nature of the relation between teacher beliefs and their efficacy, and to clarify the effect of their beliefs on their teaching behaviors in the classroom. Furthermore, what distinguishes this study from others is that it inquires into the teaching practices of English teachers from the point of view of their own teaching ability. It is mainly intended to determine to what extent English language teachers' teaching behaviors can be predicted from the degrees of their efficacy. This helps determine to what extent these teachers are aware and conscious toward their own teaching practices.

By doing so, this study tends to examine a proposed model that presents the potential effects and interconnection of activities for teacher development, teachers' teaching beliefs, efficacy and teaching practices regarding English language teaching in Taipei. This could potentially enable the designers, administrators and instructors of pre- and in-service English teacher training program to further develop and enhance their programs by focusing on the influential factors in professional development, which would make significant progress on teachers' classroom practices, and also on students' learning of English.

\subsection{Activities for Teacher Development}

It has been suggested that beliefs are relatively resistant to change. Only when they prove insufficiently, inadequately and unsatisfactory, which they only do when being challenged, individuals are motivated to replace their beliefs. The 
older beliefs are and the stronger they are, the more difficult they are to replace, even when they are based on incomplete or incorrect knowledge, and even when people are given new and correct information. The lack of change may be a result of the deep-rooted beliefs that were formed on their own learning experience as a student, and it can be assured the possibility of reinforcing or adjusting such beliefs in in-service teachers (Zheng, 2009). This indeed raises a demand for organizing activities for in-service teachers' professional development.

Additionally, Borg (2003) points out that teachers' beliefs could be influenced by schooling (i.e. teachers' previous learning experience), professional coursework (i.e. pre- and in-service teacher training), contextual factors and classroom practice, and among them, professional coursework, especially in-service teaching training, could have a direct impact on teachers' beliefs and their teaching practice.

The following activities are often used as professional development strategies for language teachers (Richards, 2005):

1) A workshop is an intensive, and short-term meeting that is designed to provide an opportunity to discuss knowledge, skill and hands-on experience on a specific topic.

2) Self-monitoring or self-observation refers to an approach to evaluate a teacher's own behavior in order to achieve a better understanding or improvement of his or her teaching.

3) Teacher support groups (i.e. study groups, teacher networks, learning circles) refers to a group of teachers working collaboratively for achieving either their individual or shared goals or both.

4) A teaching journal is a teacher's ongoing written records of self-observations, self-reflections, and other thoughts about his or her own teaching, usually in the form of a notebook, book, or electronic mode.

5) Peer observation can be defined as a colleague closely watching a teacher's lessons or part of a lesson in order to monitor some aspect of his or her teaching.

6) Teaching portfolio is a collection of documents and other items that provides reflections and self-assessment about different aspects of a teacher's teaching performance.

7) Critical incident analysis in teaching involves the documentation and analysis of teaching incidents in order to learn from them and improve practice. A critical incident is an unplanned and unanticipated event that occurs during a lesson.

8) Case analysis is a collection of information about how a teacher carries out his or her practice and resolves the issues that he or she confronts, and the use of that information to help better understand the situation and to derive principles from it.

9) Peer coaching is a procedure in which two teachers or more professional colleagues work together to help each other improve some aspect of their teaching, including solving problems, reflecting on practice, sharing ideas or new skills, and so on.

10) Team teaching (is also called pair teaching) is a process in which two or more teachers teach a class collaboratively, by sharing responsibility for planning, teaching and conducting any follow-up exercises and assessment.

11) Action research refers to teacher-conducted classroom research that seeks to clarify and resolve practical issues and problems in their own teaching by a cycle of identifying a problem or issue, trying out the solution, and observing its effects.

It should be point out that self-monitoring or self-observation, analyzing critical incidents, case analysis and team teaching are not normally included in the activities for teacher development held by the advisory team of Taipei City, and thus, they are excluded from the present study. However, English teachers are asked to attend the following two activities for their professional development (Fullan \& Hargreaves, 2002):

1) A lecture is an oral presentation intended to deliver information and hold discussions about a particular subject or topic on teaching, for example its critical information, background, theories, research and references, to a small group of teachers or members of a faculty.

2) A conference is an event for researchers or teachers to present and discuss their work, or a meeting of professionals in a given subject, concerning scientific or technical developments.

In sum, the activities above appear to build up and reinforce teachers' knowledge and understanding of their current teaching practices, such as the content to be taught, methods, strategies and exercises to be used, and the way in 
which students learn English. Putting it another way, participation in these activities would bring influence on teachers' beliefs and teaching practices (Akinsola, 2009). Hence, understanding teachers' beliefs is the first step toward realizing their thinking processes they put into lesson design and the nature of teaching practice inside the classroom.

\subsection{Teaching Beliefs}

The concept of teachers' beliefs, also called personal pedagogical systems, teacher cognition (Borg, 2003; 2006), pedagogical knowledge (Gatbonton, 1999) and personal theories (Sendan \& Roberts, 1998), is basically defined as what teachers know, believe, and think about teaching and learning (Borg, 2003). Accordingly, beliefs about language teaching can be defined as teachers' knowledge, opinions or thoughts on a variety of issues and controversies related to language teaching and learning (Horwitz, 1987).

Based on the approach of teaching-learning, teachers' beliefs are divided into two types: traditional and constructivist (Mitchell \& Myles, 2004). As for traditional beliefs, it means that teachers view their role as limited to delivering knowledge to the students in a clear, organized, and systematic way. The other type is constructivist. By giving tasks with clear steps toward solving problems or finding solutions, students follow the sequence of steps when paying attention to the target content in the classroom. It should be noted that whether both types really have to be opposed to each other is a question. Nevertheless, both types are necessary and one cannot work without the other.

Nespor (1987) identifies four characteristics of beliefs: existential presumptions (the incontrovertible, personal truths everyone holds), alter-nativity (individuals, for varying reasons, attempt to create an ideal, or alternative, situation that may differ from reality), affective and evaluative loading (beliefs typically operate independently of the cognition associated with knowledge) and episodic structure (beliefs draw their power from previous episodes or events that color the comprehension of subsequent events). Since beliefs are affective and involve a certain kind of judgment or evaluation, teachers can gain new knowledge, but are still influenced by their existing beliefs when deciding whether they accept it as true or not (Ertmer, 2005). Basically, beliefs are unchanging, and, when they change, it is not argument or reason that alters them but rather a "conversion or gestalt shift" (Nespor, 1987, p. 321).

Pajares (1992) sums up that beliefs strongly influence one's behaviors. That is to say, beliefs are a crucial ingredient in designing and planning learning, enhancing teachers' thinking, and developing suitable classroom practices. Therefore, beliefs can reflect what teachers have acquire and influence what and how they then teach to students. As Levin and Wadmany (2006) state, beliefs which are held by teachers strongly influence and improve both their teaching practices and their students' learning.

\subsection{Teaching Behaviors}

Teaching is a purposeful and systematic action in which teaching behaviors are the process of a teacher's instruction so as to deliver skills, knowledge and value for fostering or transforming students' learning (Mitchell \& Myles, 2004). In this view, teaching behaviors, based on the teacher's belief and teaching situation, are his or her decisions to implement the lessons, including objectives, content, methods, materials, exercises, resources and assessment (Chang, 2001).

Bennett (1976) defines two types of instruction. One is student-centered instruction which means that teachers tend to let students take over their learning by encouraging their participation, discussion and decision regarding their learning, and often teacher and students cooperate to what and how to teach and learn. The other is teacher-centered instruction, in which the whole instructional lesson is directed by the teacher who decides the entire instruction and assessment without listening to students' opinions or suggestions. Five characteristics can be identified as below (Mitchell \& Myles, 2004):

1) Teaching is interactive which involves both teacher and students, and they work together for achieving the target goals.

2) Teacher plays an important role during teaching process in order to deliver the teaching, deal with problems, and assess the teaching and learning outcomes.

3) Teaching is a purposeful activity which means that teaching is not only to pass knowledge on to students but also to develop students' personal competence and value.

4) Teachers' instructional practices are influenced by the teachers' beliefs, and this is because beliefs are the main driving force for activities teachers perform with their students inside the classroom.

5) Teaching process should include content, methods, materials, activities, assessment and students' interaction in order to foster students' learning achievement. 
Obviously, teaching outcomes and students' performance are influenced by the actual teaching practices and this differs depending heavily on teachers themselves (Mitchell \& Myles, 2004). To put this into other words, if the teacher's knowledge of how students learn is well-structured and organized instruction delivered by the teacher only, students' learning would be limited to specific content and methods. By contrast, if the situation is in a free and open-to-discussion environment, the scope of learning would be more extended and expanded. However, it should be emphasized that either instruction would be appropriate to different teaching settings and students as far as the effects of both instructions and learners' differences are concerned.

Thus, the current study aims at identifying whether there is a correlation between elementary school teachers' beliefs and teaching practices from their self-reported perspectives toward English teaching. Teachers' beliefs and practices are important for understanding and improving educational processes. They are closely linked to teachers' strategies for coping with challenges in their daily professional life and to their general well-being, and they shape students' learning environment and influence students' achievement. A substantial research suggests that teachers' beliefs about teaching affect their teaching practices (see reviews by Clark \& Peterson, 1986; Fang, 1996; Kagan, 1992; Thompson, 1992).

However, Huang, Liu \& Shiomi (2007) asserted that the teachers' teaching practices are affected by what those teachers believe their abilities to teach and this will lead to the desired outcomes of their teaching and students' learning. This attention given to teachers' efficacy could potentially improve the overall teaching practices in English teaching.

In sum, considering that teachers' ideas and actions can be defined as the beliefs and behaviors of their teaching respectively, four oriented categories of teacher perspectives to describe teacher action and ideas can be identified (Tabachnick \& Zeichner, 1985), as follows:

1) Knowledge and curriculum: Knowledge is either public or personal, product or process, and certain or problematic. Learning can be seen as either fragmented or holistic, unrelated or integrated, and a collective activity or an individual activity. Regarding teacher control over pupil learning, this category is either high or low.

2) Teacher-pupil relationship: In this category, it can be either distance or personal teacher-pupil relationship, and the level of teachers' control over pupil behaviors is either high or low.

3) The teacher's role: Three aspects of the teachers' role are included, namely, determining what to teach, deciding how to teach and relating to school rules and regulation. The decision in all three areas is either bureaucratic (educational authorities), or independent (individual teacher).

4) Student diversity: Children are either unique or members of a category, and school curriculum and student behavior are either universalism or particularism. As to allocation of school resources, it can be either equal or differential. Common culture or subgroup consciousness is emphasized in school curriculum, and career orientation in relation to student diversity is either little restriction or restricted.

The above four aspects of teachers' perspectives can be defined as the key components of their beliefs and behaviors in English language teaching, which are included in the instrument of this study.

\subsection{Efficacy}

Efficacy is defined as "people's judgments of their capabilities to organize and execute courses of action required to attain designated types of performances" (Bandura, 1986, p. 391). That is to say that individuals have the power to exercise some control over their living and working environments, and in this respect, Bandura (1997) attributes efficacy to four primary sources: mastery experience (one's success or failure in performing a specific task), vicarious experience (one's observation of others' performance), social persuasion (positive or negative feedback about one's abilities from others), and psychological and affective states (one's affective states such as stress, anxiety, and fear when performing tasks). Among them, mastery experience has been seen as the most powerful source that determines and influences the formation of one's behaviors (Bandura, 1997; Morris, Usher, \& Chen, 2016).

Obviously, efficacy can be seen as "whether individuals think in self-enhancing or self-debilitating ways; how well they motivate themselves and persevere when they face any difficulties; the quality of their emotional life and vulnerability to stress" (Tilfarlioğlu \& Cg்nkara, 2009, p.130). Thus, it evolves from self-concept, which can be defined as the sum of an individual's perception of themselves (Cayci, 2011), and is reported as an important predictor of how much effort individuals make and how well they persevere when coping with obstacles, and how effectively people can adjust their motivation, behavior and achievement (Schunk, Meece, \& Pintrich, 2014), for it determines ones' willingness to expend effort in the activity concerned (Wigfield \& Guthrie, 1997). Efficacy has 
been intensively investigated in various fields, particularly in educational settings (Schunk, Meece \& Pintrich, 2014). Researchers have given substantial evidence highlighting the critical influence of teachers' efficacy, especially on the teaching and learning process (Bandura, 1997; Morris, Usher, \& Chen, 2016; Tschannen-Moran \& Hoy, 2001).

Moreover, Bandura (1977) defines teacher efficacy as a teacher's confidence in his/her own ability to create a teaching environment, which fosters students' engagement and learning. Similarly, Tschannen-Moran et al. (1998, p. 233) consider teacher efficacy as a teacher's beliefs in his or her ability to organize and take action to "successfully accomplish a specific teaching task in a particular context". In the same way, Tschannen-Moran and Hoy (2001) consider teacher efficacy as an influential factor that may determine failure or success in all aspects of teaching. That is, teachers with high efficacy seem to make more effort and demonstrate better planning, organizing, and conducting exercise and activities in their teaching (Pajares, 1992).

Research results show a positive relation between teachers' perception of their own capacity and their behaviors supporting student success (Goddard \& Goddard, 2001). Teachers' positive efficacy leads to positive changes in their teaching and students' behaviors (Gibson \& Dembo, 1984), and motivates and encourages them to create a positive atmosphere and an effective process for students' success (Bandura, 1993). Also, teachers with high levels of efficacy are more willing to explore and adopt new approaches and strategic ideas in the classroom (Calik, Sezgin, Kavgaci, \& Kilinc, 2012; Duyar, Gumus, \& Bellibas, 2013; Goddard, Goddard, Eun \& Miller, 2015). This uniqueness of an English teacher's role inevitably raises attention to the effects of an English teacher's efficacy on their teaching behaviors, and students' learning (Klassen, Tze, Betts \& Gordon, 2011).

\subsection{Research Hypotheses Model}

Based on the discussion above, four variables related to elementary school English teachers were investigated, including the latent independent variables of activities for teacher development (ATD), teaching beliefs (TB) and teaching efficacy (TEF), and the observable dependent variables of teaching behaviors (TBH). Accordingly, the research hypotheses are:

1) H1: Activities for teacher development (ATD) has a positive effect on teaching beliefs (TB), teaching efficacy (TEF) and teaching behaviors (TBH).

2) H2: Teaching beliefs (TB) have a positive effect on teaching efficacy (TEF) and teaching behaviors (TBH).

3) H3: Teaching efficacy (TEF) has a positive effect on teaching behaviors (TBH).

\section{Method}

\subsection{Research Subjects}

The subjects of this study were 197 English teachers of elementary schools in Taipei City in Taiwan. Their demographics are described as follows. 154 of the participants (78.2\%) were females, compared with 43 males (21.8\%). With regard to their majors, all have been studying English language teaching or English-related (e.g. English, foreign languages \& literature) as a school subject, and $38.7 \%$ held a bachelor's degree and $61.3 \%$ received a master's degree. Their English language proficiency was considered as at a minimum of B2 (upper intermediate) level in the Common European Framework of Reference for Languages: Learning, teaching, assessment (CEFR). As far as their teaching experience is concerned, they have been teaching English as a school subject for 3 to 19 years. Substitute teachers who would have various teaching hours based on the school which recruited them, were excluded from this study.

\subsection{Research Instrument}

A questionnaire, consisting of four sections with 76 question items in total, which was adapted from Pintrich (1989, 2003), Richard-Amato (1996), and Horwitz, Horwitz and Cope (1986), respectively. The first section was activities for teacher development (ATD, 9 items). Section two collected information about teachers' teaching beliefs (TB, 16 items) which was further divided into four sub-sections of curriculum and instruction (TB-CI, 4 items), teacher's role (TB-TR, 4 items), teacher-student relation (TB-TSR, 4 items) and students' difference (TB-SD, 4 items). And section three was for finding out teachers' teaching efficacy (TEF, 35 items), dividing into five sub-dimensions of self-efficacy (SE, 7 items), teaching plan and preparation expectation (PPE, 7 items), teaching strategies (TS, 7 items), classroom management (CM, 7 items) and teaching evaluation (TE, 7 items). The final section was about teachers' teaching behaviors (BH, 16 items), including curriculum and instruction (BH-CI, 4 items), teacher's role (BH-TR, 4 items), teacher-student relation (BH-TSR, 4 items) and students' difference (BH-SD, 4 items). The subjects were asked to respond to each item question by a rating scale with numeric values of $1,2,3$, and 4 corresponding to strongly disagree, disagree, agree, and strongly agree, respectively. With this scale, the higher the 
score given, the higher the perspectives the subjects held on the question item.

The first drafts of the questionnaire were given to three elementary school English teachers for examining the suitability of wording and question items so as to establish the expert validity of the instrument. Based on their comments, some question items were revised to make them appropriate to the context and subjects in the study. Then, after being completed by 28 elementary school English teachers, the data was analyzed to examine its reliability and the overall value of Cronbach's alpha $(\alpha)$ was .857 ( $\mathrm{ATD}=.840, \mathrm{~TB}=.819, \mathrm{BH}=.859, \mathrm{TEF}=.897$ ). Accordingly, the questionnaire can be considered as having good internal consistency (George \& Mallery, 2003). After that, a google forms of the questionnaire was created and sent to 240 English teachers in Taipei City via email and 197 completed questionnaires were returned, accounting for an effective retrieval rate of $82.5 \%$ which was considered reasonable (Carmines \& McIver, 1981).

\subsection{Data Analysis}

Questionnaire data were collected during the second academic semester in 2019 and were analyzed by SPSS/PC 18.0. First, the descriptive statistic of the four variables (i.e. ATD, TB, TEF and TBH) were carried out in terms of mean scores and standard deviations. Then, the Pearson correlation was conducted to examine the relationship between the four variables. After that, regression analysis and path analysis were used for reviewing the causal relationship and the predictive power of the four variables so as to test the three research hypotheses.

\section{Results}

\subsection{Descriptive Statistic}

The results of descriptive statistics of the main variables are gievn in Table 1 below. It was found that ATD and TBH were less than 3.0, which appears that the teachers were less confident about professional development and their teaching behaviors, and the ATD is the lowest with a mean of 2.720. As for the other two variables, the mean is just above 3.40, and the TB $(\chi=3.462)$ is the highest. This result seems to suggest that the teachers hold strong beliefs and better efficacy of their teaching.

Table 1. Descriptive statistics of the main variables

\begin{tabular}{lcc}
\hline$n=197$ & Mean & Std. Deviation \\
\hline Activities for teacher development (ATD) & 2.720 & .474 \\
Teaching beliefs (TB) & 3.462 & .211 \\
Teaching efficacy (TEF) & 3.427 & .385 \\
Teaching behaviors (TBH) & 2.800 & .344 \\
\hline
\end{tabular}

\subsection{Correlation Analysis}

The results of the Pearson correlation analysis is shown in Table 2 below. As can be seen, the ATD has a low degree of correlation with TB $(r<.333)$, reaching a significant level $(r=.161$; Sig=.05), and the correlations of TB and BH also reached a significant level ( $r=.659$; $\mathrm{Sig}=.01)$, being at a medium degree of correlation ( $r=.333 \sim .666)$. Apart from these, all the other four correlations have the low degree of correlation $(r<.333)$, and did not reach a significant level.

Table 2. Correlation of the main vriables

\begin{tabular}{|c|c|c|c|c|}
\hline & ATD & TB & TEF & $\mathrm{BH}$ \\
\hline ATD & 1 & & & \\
\hline $\mathrm{TB}$ & $.161 *$ & 1 & & \\
\hline TEF & .023 & .074 & 1 & \\
\hline $\mathrm{BH}$ & -.038 & $.659 * *$ & .098 & 1 \\
\hline
\end{tabular}




\subsection{Regression Analysis}

In order to understand whether there is a cause-effect relationship among strategies for professional development, teachers' teaching belief, teaching efficacy and teaching behaviors, a regression analysis was employed for examining correlations of the four variables, and testing the three research hypotheses.

\subsubsection{Teaching Beliefs}

As shown in Table 3, the $\mathrm{R}^{2}$ value of teaching beliefs' regression model summary is $2.6 \%$. According to the results of the ANOVA summary in Table 4, this model accounts significantly for the dependent variables $(F=5.180, \operatorname{Sig}=.024)$; that is, activities for teacher development (ATD) is predicted significantly by their teaching beliefs (TB), which means that belief contributes to this prediction $(\beta=-.161$; $\mathrm{Sig}=.05)$, based on the results of coefficient analysis in Table 5; however, it should be mentioned that its $\beta$ value is negative. In other words, changes in activities for teacher development (ATD) are related to changes in the teaching beliefs (TB).

Table 3. Teaching beliefs' regression model summary

\begin{tabular}{ccccc}
\hline Model & $\mathrm{R}$ & $\mathrm{R}$ Square & Adjusted R Square & Std. Error of the Estimate \\
\hline 1 & $.161(\mathrm{a})$ & .026 & .021 & .3814 \\
\hline
\end{tabular}

(a) Predictors (Constant): ATD

Table 4. Teaching beliefs' ANOVA summary

\begin{tabular}{clrrrrr}
\hline Model & & Sum of Square & df & Mean Square & F & Sig. \\
\hline 1 & Regression & .753 & 1 & .753 & $5.180^{*}$ & .024 \\
& Residual & 28.362 & 195 & .145 & & \\
& Total & 29.115 & 196 & & & \\
\hline
\end{tabular}

$* p<.05$

Table 5. Summary of teaching beliefs' findings

\begin{tabular}{|c|c|c|c|c|c|c|c|}
\hline \multirow{2}{*}{\multicolumn{2}{|c|}{ Model }} & \multicolumn{2}{|c|}{$\begin{array}{c}\text { Nonstandardized } \\
\text { Coefficients } \\
\end{array}$} & \multirow{2}{*}{$\begin{array}{c}\text { Standardized } \\
\text { Coefficients } \\
\text { Beta } \\
\end{array}$} & \multirow[t]{2}{*}{$\mathrm{T}$} & \multicolumn{2}{|c|}{ Collinearity Statistics } \\
\hline & & B & Std. Error & & & Tolerance & VIF \\
\hline \multirow[t]{2}{*}{1} & (Constant) & 3.818 & .159 & & $24.081 * * *$ & & \\
\hline & ATD & -.131 & .057 & -.161 & $2.276^{*}$ & 1.000 & 1.000 \\
\hline
\end{tabular}

$* \overline{p<.05 ; * * * p<.001}$

\subsubsection{Teaching Efficacy}

The result of teaching efficacy' regression model summary is given in Table 6 , and the $\mathrm{R}^{2}$ value is .007 , indicating that $0.7 \%$ of the dependent variables can be explained by the model containing ATD and TB. According to the results of the ANOVA analysis in Table 7, this model accounts insignificantly for the dependent variables $(F=.664$, n.s.), which would suggest that changes in the predictor are not associated with changes in the response variable. In addition, when the beta value was analyzed, the results (in Table 8) show that neither activities for teacher development (ATD) nor teaching belief (TB) contributes significantly to teachers' teaching efficacy (TEF).

Table 6. Teaching efficacy's regression model summary

\begin{tabular}{ccccc}
\hline Model & $\mathrm{R}$ & $\mathrm{R}$ Square & Adjusted R Square & Std. Error of the Estimate \\
\hline 2 & $.082(\mathrm{a})$ & .007 & -.003 & .2116
\end{tabular}

(a) Predictors (Constant): ATD, TB 
Table 7. Teaching efficacy's ANOVA summary

\begin{tabular}{clrrrrc}
\hline Model & & Sum of Square & $\mathrm{df}$ & Mean Square & F & Sig. \\
\hline 2 & Regression & .059 & 2 & .030 & .664 & .516 \\
& Residual & 8.690 & 194 & .045 & & \\
& Total & 8.750 & 196 & & & \\
\hline
\end{tabular}

Table 8. Summary of teaching efficacy's findings

\begin{tabular}{|c|c|c|c|c|c|c|c|}
\hline \multirow[t]{2}{*}{ Model } & & \multicolumn{2}{|c|}{$\begin{array}{c}\text { Nonstandardized } \\
\text { Coefficients }\end{array}$} & \multirow{2}{*}{$\begin{array}{c}\text { Standardized } \\
\text { Coefficients } \\
\text { Beta } \\
\end{array}$} & \multirow[t]{2}{*}{$\mathrm{T}$} & \multicolumn{2}{|c|}{ Collinearity Statistics } \\
\hline & & B & Std. Error & & & Tolerance & VIF \\
\hline \multirow[t]{3}{*}{2} & (Constant) & 3.231 & .175 & & $18.421 * * *$ & & \\
\hline & ATD & .016 & .032 & .036 & .502 & .974 & 1.027 \\
\hline & $\mathrm{TB}$ & .044 & .040 & .080 & 1.104 & .974 & 1.027 \\
\hline
\end{tabular}

\subsubsection{Teaching Behaviors}

Table 9 shows the results of regression analysis and by examining the $\mathrm{R}^{2}$ value, this model accounts for $44.1 \%$ of the dependent variables. The results of the ANOVA analysis in Table 10 indicates that this model does not account significantly for the dependent variables $(F=50.654$, Sig=.001), but by carrying the coefficient analysis, the beta value in Table 11 demonstrates that teachers' teaching belief contributes significantly to the prediction of teachers' teaching behaviors $(\beta=.666$; $\mathrm{Sig}=.001)$.

Table 9. Teaching behaviors' regression model smmary

(a) Predictors (Constant): SPD, TB, EF

\begin{tabular}{ccccc}
\hline Model & $\mathrm{R}$ & R Square & Adjusted R Square & Std. Error of the Estimate \\
\hline 3 & $.664(\mathrm{a})$ & .441 & .432 & .2864 \\
\hline
\end{tabular}

Table 10. Teaching behaviors' ANOVA summary

\begin{tabular}{clrrrrr}
\hline Model & & Sum of Square & df & Mean Square & F & Sig. \\
\hline 3 & Regression & 12.467 & 3 & 4.156 & $50.654^{* * *}$ & .000 \\
& Residual & 15.833 & 194 & .082 & & \\
& Total & 28.300 & 196 & & & \\
\hline
\end{tabular}

$* * * p<.00 \overline{1}$

Table 11. Summary of teaching behaviors' findings

\begin{tabular}{|c|c|c|c|c|c|c|c|}
\hline \multirow[t]{2}{*}{ Moc } & & \multicolumn{2}{|c|}{$\begin{array}{l}\text { Nonstandardized } \\
\text { Coefficients }\end{array}$} & \multirow{2}{*}{$\begin{array}{c}\text { Standardized } \\
\text { Coefficients } \\
\text { Beta } \\
\end{array}$} & \multirow[t]{2}{*}{$\mathrm{T}$} & \multicolumn{2}{|c|}{ Collinearity Statistics } \\
\hline & & B & Std. Error & & & Tolerance & VIF \\
\hline \multirow[t]{4}{*}{3} & (Constant) & .241 & .394 & & .612 & & \\
\hline & ATD & .054 & .044 & .068 & 1.243 & .973 & 1.028 \\
\hline & $\mathrm{TB}$ & .657 & .054 & .666 & $12.170 * * *$ & .968 & 1.033 \\
\hline & $\mathrm{EF}$ & .084 & .097 & .047 & .863 & .993 & 1.007 \\
\hline
\end{tabular}




\subsubsection{Path Analysis}

Figure 1 below presents the result of path analysis and standardized coefficients. As far as direct effect is concerned, two paths are significant, that is, activities for teacher development (ATD)-teaching belief (TB), and teaching belief (TB)-teaching behaviors (TBH). For ATD-TB path, the significant effect of ATD on TB $(\beta=-.161$; Sig=.05) reveals that the more ATD teachers attend the stronger their TB become. As can be seen in the TB-TBH path, TB had a significant effect on TBH ( $\beta=.666$; Sig=.001), which suggests that the more positive the TB is the better the TBH is likely to be.

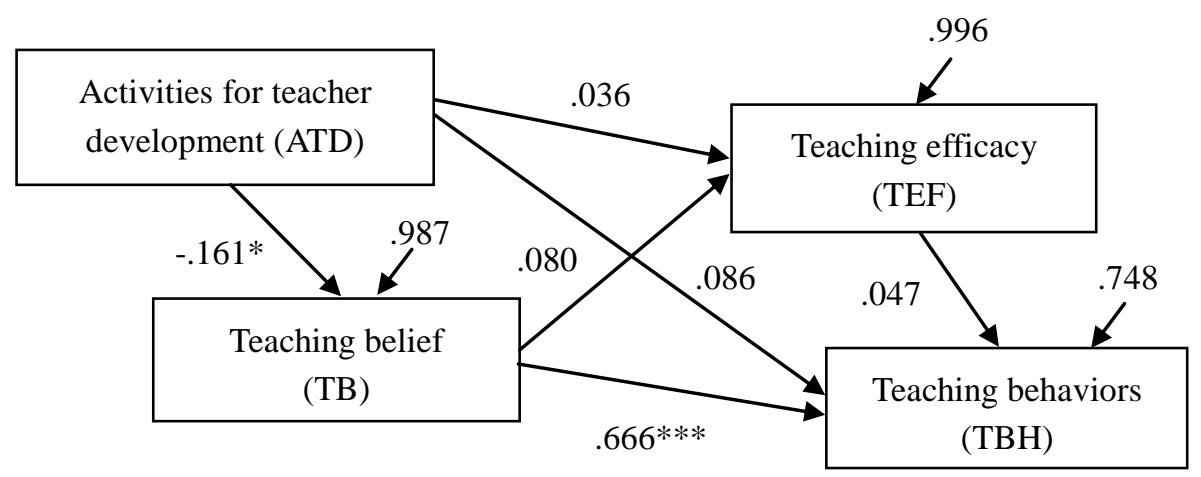

Figure 1. Path analysis and standardized coefficients

\section{Discussion}

The purpose of the present study was to identify the relationships among four factors (i.e. strategies for teacher development, teaching beliefs, teaching efficacy and teaching behaviors) in English language teaching in elementary schools, and to reveal the prediction of the potential influence of these four elements on each other by testing the three research hypotheses via path analysis. The results indicate that a significant effect was found in ATD-TB and TB-TBH, in other words, when teachers' teaching beliefs (TB) was concerned, strategies for teacher development (ATD) should be emphasized, and while a close look at the effect of the teaching beliefs (TB) on their teaching behaviors (TBH), the former seemed to enhance a positive impact on the latter. These findings appeared to suggest a chain of events; that is, how they teach in the classroom can be seen as a result of what they believe in English language teaching, and this tendency is led by their commitment to what activities for teacher development they participated. This is consistent with the reasearch findings of Dörnyei (2001), Dörnyei and Clèment (2002), Ushioda (2008) and Wesely (2009). This path provides some empirical insights into the relationship among the four factors as follows.

First of all, it should be pointed out that English language teaching beliefs are associated significantly with the activities for teacher development teachers have participated in. A possible explanation might be that most activities for in-service English teachers in Taipei were organized and conducted by the city's advisory team whose members are mainly elementary school English teachers selected through examinations and interviews. As for the activities, scholars with related specialty, advisory team members or experienced English teachers are invited to present and discuss the current practical issues, methods and approaches of ELT, or to share their successful teaching experiences, rather than to focus on theoretical knowledge. By doing this, teachers who are less experienced in teaching or less confident in trying new methods are more likely to gain from taking part in such activities. That is to say, the more teachers' participation in these activities, the more positive their perspectives on teaching, and this highlights the indispensable need and importance of ongoing professional training activities for in-service teachers that might determine the practice and outcomes of their teaching. However, the effect of each activity on the change of teachers' beliefs is unclear, and this issue should be emphasized in future study.

Apart from that, our finding showed that there was no significant direct effect of activities for teacher development on teaching behaviors and efficacy, respectively. For the former, it is reasonable to assume that teachers' actual teaching practice in English lessons is affected by any form of training, especially professional development activities for in-service teachers. That is, teachers would probably adopt or adapt what they have gained from participating in the professional development activities and then resolve to practice in their English lessons whenever and wherever is needed, yet this is not the case in this study. If teachers who do not acquire new methods or techniques are less proficient and capable to perform effectively in the classroom, which would clearly result in a 
decline of students' learning, future research should pay attention to this concern.

For the latter, no matter what types of activities for teacher development, teaching efficacy depends substantially on what should be taught and how to teach, but what cannot be denied is that learning environment and students' personal factors (i.e. learning conditions and proficiency) in particular are crucial factors (Brophy, 2004; Sheu, 2015). In this sense, the correlation between activities for teacher development and teaching efficacy is weaken. This appears to be a starting point of connecting activities for teacher development and teaching efficacy for the city's advisory team to identify some possible issues to be presented and discussed in the activities so that the instructional and scholastic success can be achieved. Future research should take this interconnection into account in a longitudinal study and such a study should be able to see the whole picture of the influential role of teachers and students in English language teaching and learning.

Consistent with previous research (Clark \& Peterson, 1986; Kagan, 1992), the findings confirm that teachers' beliefs served as a prominent factor in affecting their teaching practice and would potentially impair the effects of their teaching if the perceptions of their own teaching is insufficient. This is probably true for novice teachers whose teaching experiences is limited since they are at the early stages of teaching career. Thus, it is very important to be involved in the development activities for being acquainted with other's successful teaching experiences, and then to adopt them whenever is necessary so as to trigger their teaching profession and skills effectively in their teaching situation.

By contrast, as to other teachers, it is generally believed that how they teach in the classroom is often affected by what they already know regarding English language teaching. If teachers do not keep track of current trend in ELT, they will rely heavily on an old-fashioned manner and tend to just get through the lesson in a causal way, and in this context, students definitely are not motivated to learn, which, in turn, declines their learning achievement. In fact, teachers should be aware of the necessity of participation in activities of teacher development and its benefits on their teaching practice no matter what their experiences are and level of familiarity with teaching is.

It is surprising that what teachers believe might not be a direct predictor of how well they think they can perform in their teaching, leading us to speculate on reasons that interfere with such a prediction. To begin with, the efficacy is an act of teachers' self-evaluation of their engagement, ability and achievement in English lessons rather than of their perceptions of teaching. It is also a consequence of a closer inspection on their teaching quality rather than on the suitability and applicability of the teaching content. Aiming at creating an appropriate lesson, teachers would apply what they have possessed regarding teaching English to design a curriculum by establishing goals, selecting methods, materials and exercises, and would make any adjustment depending on the actual situation they encounter during teaching. Thus, it can be anticipated that the efficacy of their teaching is not an end when applying their beliefs to design such a lesson, but the effectiveness, sufficiency and appropriation of their teaching would be for the lessons afterwards, hence the path between teaching beliefs and efficacy was not significantly related. Concomitant to this is a research call for probing into teachers' opinions about such an irrelevant relationship in order to shed light on the influential elements of English language teaching.

Furthermore, as expected, relation between teacher's efficacy and teaching behaviors was not significant in this study. Apparently, how well they think in their teaching is not always the same as how well they actually perform in the classroom, and sometimes teachers who are more confident and familiar with their teaching, do not seem to become aware of their failure in the lessons. It is also true to say that teachers' positive efficacy of their own teaching is not equivalent to a positive effect on students' learning, since it takes time to foster students' success in language learning. This means that a teacher's misconception about the success of his or her teaching effects is more likely to deteriorate students' learning. This finding is not accordant with the study by Bandura (2012), Morris, Usher and Chen (2017), and Tschannen-Moran and Hoy (2001), indicating that teacher' efficacy related significantly with the effects of their performance. This issue should be treated with caution, and thus, is suggested to adopt lesson observations to explore the impact of the efficacy on the classroom practices in future study.

Similarly, students' personal traits (i.e. proficiency, characteristics, attitude, motivation and experiences) have been suggested to play a key role in the success of teaching and learning (Sheu, 2016, 2017), and for that reason, teachers inevitably need to not only take these traits into account when they design a lesson, but also raise their awareness of these traits in implementing the lesson. The more acquainted with these traits a teacher is the stronger the teaching efficacy and the better the learning outcomes. As Poulson, Avramidis, Fox, Medwell and Wray (2001) point out, students' achievement can be used as an indication of teachers and students' performance in teaching and learning. Accordingly, this will lead to a consideration to include students' personal traits and achievement in future study so as to reveal their relations with other variables. 
An additional look at the results indicates that the three components are highly and significantly correlated. This finding appears to indicate an operation of English language teaching; that is, activities of teacher development enrich teachers' belief, and the belief improves teaching behaviors, and this process is led by the potentials of what they have obtained from participating in the activities for professional development. The immediate matter is to create a professional development environment by providing practicable teaching experiences relevant to teachers' authentic classroom situations and let them utilize such an improvement as a powerful incentive to bring about effective teachers' competence in the present English teaching settings; by this, teachers should be able to become more familiar with the pragmatic experiences of teaching English in terms of raising the effects of their teaching and students' learning of English. Since there is a strong likelihood that fostering teachers' professional belief will favor their teaching behaviors, it is vital for educational authorities to do whatever means they can to stimulate English teachers' pedagogical capability, and more importantly, close attention should be paid to those who are at early phases of their teaching life, by encouraging them to employ whatever is appropriate to their students in their instructions (Cabaroglu \& Roberts, 2000). In other words, when teachers transfer the pedagogical gains received from the professional development orientations into a pragmatic environment for their lessons, their teaching and students' academic performance will be triggered. This issue should be dealt with seriously in English teaching and learning situations.

Adding the issues above together, a feasible scheme is to focus on encouraging teachers to attend any form of professional development, to equip themselves with appropriate pedagogical and instructional methods and skills, and then to do their best to adopt or appropriately adapt them in their teaching circumstance, and if teachers can do so, they can definitely expect to see a successful outcome in their teaching and students' learning. This is what our self-expectation and mission are, and we as teachers should try our utmost to achieve.

In conclusion, after taking part in professional development activities, teachers should value the importance and necessity of connecting what they have in mind with their teaching practice in the classroom. When teachers see these activities as irrelevant to their teaching, they become uncertain of whether or not they should include them in their teaching, or to make matters worse, they will decline to take any action to make their teaching more effective. At the end, this process turns into a vicious circle; that is to say, they need professional development activities to make their teaching more effective but without better efficacy they do not perceive the essentiality of these activities. This is what we as teachers should be reluctant to do and at least should avoid.

\section{References}

Abraham, R. G., \& Vann, R. J. (1987). Strategies of two language learners: A case study. In A. Wenden \& J. Rubins (Eds.), Learner strategies in language learning (pp. 85-102). Englewood Cliffs, NJ: Prentice-Hall.

Akinsola, M. K. (2009). Students' avoidance strategies and mathematics achievement. West African Journal of Education, 29, 22-32.

Bailey, K. M., Curtis, A., \& Nunan, D. (2001). Pursuing professional development: The self as source. TESL EJ, 6(1). Retrieved from http://tesl-ej.org/ej21/r4.html

Bandura, A. (1977). Self-efficacy: Toward a unifying theory of behavioral change. Psychological Review, 84(2), 191-215. https://doi.org/10.1037/0033-295X.84.2.191

Bandura, A. (1986). Social foundations of thought and action: A social cognitive theory. Englewood Cliffs, NJ: Prentice Hall.

Bandura, A. (1993). Perceived self-efficacy in cognitive development and functioning. Educational Psychologist, 28(2), 117-148. https://doi.org/10.1207/s15326985ep2802_3

Bandura, A. (1997). Self-efficacy: The exercise of control. New York, NY: Worth Publishers.

Bandura, A. (2012). On the functional properties of perceived self-efficacy revisited. Journal of Management, 38(1), 9-44. https://doi.org/10.1177/0149206311410606

Bennett, S. N. (1976). Teaching styles and pupil progress. London, UK: Open Books.

Borg, S. (2003). Teacher cognition in language teaching: A review of research on what language teachers think, know, believe, and do. Language Teaching, 36(2), 81-109. https://doi.org/10.1017/S0261444803001903

Borg, S. (2006). Teacher cognition and language education: Research and practice. London, UK: Continuum.

Borich, G. (1999). Dimensions of self that influence effective teaching. In R. P. Lipka \& T. M. Brinthaupt (Eds.), The role of self in teacher development (pp. 92-117). Albany, NY: State University of New York Press. 
Brophy, J. E. (2004). Motivating students to learn (2nd ed.). Boston, MA: McGraw-Hill. https://doi.org/10.4324/9781410610218

Cabaroglu, N., \& Roberts, J. (2000). Development in student teachers' pre-existing beliefs during a 1-year PGCE programme. System, 28(3), 387-402. https://doi.org/10.1016/S0346-251X(00)00019-1

Çalik, T., Sezgin, F., Kavgaci, H., \& Kilinc, C. A. (2012). Examination of relationships between instructional leadership of school principals and self-efficacy of teachers and collective teacher efficacy. Educational Sciences: Theory and Practice, 12(4), 2498-2504.

Carmines, E. G., \& McIver, J. P. (1981). Analyzing models with unobserved variables: Analysis of covariance structures. Thousand Oaks, CA: Sage.

Cayci, B. (2011). The relationship between the elementary teacher candidates' teacher efficacy and their attitudes toward the profession. Education, 132(2), 402-418.

Chung, C. C. (2001). Educational psychology. Taipei, TW: Tunghua.

Clark, C. M., \& Peterson, P. L. (1986). Teachers' thought processes. In Wittrock, M. C. (Ed.), Handbook of research on teaching (3rd ed., pp. 255-296). New York, NY: Macmillan.

David, H., Olwen, M., Janis, J., Mary, L., \& Anne, C. (2003). Teachers' perceptions of continuing professional development. Nottingham, UK: Queen's Printer.

Dornyei, Z. (1998). Motivation in second and foreign language learning. Language Teaching, 31, 117-135. https://doi.org/10.1017/S026144480001315X

Dörnyei, Z. (2001). Teaching and researching motivation. Longman, UK: Pearson Education.

Dörnyei, Z. (2005). The psychology of language learner: Individual differences in second language acquisition. Mahvah, NJ: Lawrence Erlbaum.

Dörnyei, Z., \& Clèment, R. (2002). Motivational characteristics of learning different target languages: Results of a nationwide survey. In Z. Dörnyei \& R. Schmidt (Eds.), Motivation and second language acquisition (pp. 399-432). Honolulu, HI: University of Hawaii Press.

Duyar, I., Gumus, S., \& Bellibas, M. S. (2013). Multilevel analysis of teacher work attitudes: The influence of principal leadership and teacher collaboration. International Journal of Educational Management, 27(7), 700-719. https://doi.org/10.1108/IJEM-09-2012-0107

Ertmer, P. A. (2005). Teacher pedagogical beliefs: the final frontier in our quest for technology integration?. Educational Technology Research and Development, 53(4), 25-39. https://doi.org/10.1007/BF02504683

Feng, B. (1996). Degree of teachers' job satisfaction and the contributing factors. Educational Research, 2, 42-49.

Fullan, M., \& Hargreaves, A. (2002). Teacher development and educational change. New York, NY: Routledge.

Gatbonton, E. (1999). Investigating experienced ESL teachers' pedagogical knowledge. The Modern Language Journal, 83(1), 35-50. https://doi.org/10.1111/0026-7902.00004

George, D., \& Mallery, P. (2009). SPSS for Windows step by step: A simple guide and reference (4th ed.). Boston, MA: Allyn \& Bacon.

Gibson, S., \& Dembo, M. H. (1984). Teacher efficacy: A construct validation. Journal of Educational Psychology, 76, 569-582. https://doi.org/10.1037/0022-0663.76.4.569

Goddard, R., \& Goddard, Y. (2001). A multilevel analysis of the relationship between teacher and collective efficacy in urban schools. Teaching and Teacher Education, 17, 807-818. https://doi.org/10.1016/S0742-051X(01)00032-4

Goddard, R., Goddard, Y., Eun, S. K., \& Miller, R. (2015). A theoretical and empirical analysis of the roles of instructional leadership, teacher collaboration and collective efficacy beliefs in support of student learning. American Journal of Education, 121(4), 501-530. https://doi.org/10.1086/681925

Golding, L., \& Gray, I. (2006). Continuing professional development for clinical psychologists: A practical handbook. Oxford, UK: Blackwell. https://doi.org/10.1002/9780470754900

Hayes, D. (2000). Cascade training and teachers' professional development. ELT Journal, 54(2), 135-145. https://doi.org/10.1093/elt/54.2.135 
Horwitz, E. (1987). Surveying student beliefs about language learning. In A. Wenden \& J. Rubin (Eds.), Learner strategies in language learning (pp. 119-129). Englewood, NJ: Prentice-Hall.

Huang, X., Liu, M., \& Shiomi, K. (2007). An analysis of the relationships between teacher efficacy, teacher self-esteem and orientations to seeking help. Social Behavior and Personality: An International Journal, 35, 707-716. https://doi.org/10.2224/sbp.2007.35.5.707

Jacobs, G. M., \& Farrell, T. (2001). Paradigm shift: Understanding and implementing change in second language education. TESL EJ, 5(1). Retrieved from http://www.kyoto-su.ac.jp/information/teslej/ej17/toc.html

Jasper, M. (2006). Professional development, reflection, and decision-making. Oxford, UK: Blackwell.

Johnson, K. E. (1994). The emerging beliefs and instructional practices of preservice English as a second language teachers. Teaching and Teacher Education, 10(4), 439-452. https://doi.org/10.1016/0742-051X(94)90024-8

Kagan, D. M. (1992). Implications of research on teacher belief. Educational Psychologist, 27, 65-90. https://doi.org/10.1207/s15326985ep2701_6

Karaaslan, A. D. (2003). Teachers' perceptions of self-initiated professional development: A case study on Bakent University English Language teachers (Unpublished master thesis). Middle East Technical University.

Kerka, S. (2003). Does adult educator professional development make a difference: Myths and realities. Washington, DC: ERIC.

Klassen, R. M., Tze, V. M., Betts, S. M., \& Gordon, K. A. (2011). Teacher efficacy research 1998-2009: Signs of progress or unfulfilled promise? Educational Psychology Review, 23(1), 21-43. https://doi.org/10.1007/s10648-010-9141-8

Lau, K. L. (2006). Implementing strategy instruction in Chinese language classes: A school-based Chinese reading strategy instruction program. Educational Research, 48(2), 195-209. https://doi.org/10.1080/00131880600732280

Levin, T., \& Wadmany, R. (2006). Teachers' beliefs and practices in technology-based classrooms: A developmental view. Journal of Research on Technology in Education, 39(2), 157-181. https://doi.org/10.1080/15391523.2006.10782478

Luke, A., \& McArdle, F. A. (2009). A model for research-based sate professional development policy. Asia-Pacific Journal of Teacher Education, 37(3), 231-251. https://doi.org/10.1080/13598660903053611

Maggioni, L., \& Parkinson, M. M. (2008). The role of teacher epistemic cognition, epistemic beliefs, and calibration in instruction. Educational Psychology Review, 20(4), 445-461. https://doi.org/10.1007/s10648-008-9081-8

Mitchell, R., \& Myles, F. (2004). Second language learning theories. New York, NY: Hodder Arnold.

Mori, Y. (1999). Epistemological beliefs and language learning beliefs: What do language learners believe about their learning?. Language Learning, 49, 377-415. https://doi.org/10.1111/0023-8333.00094

Morris, D. B., Usher, E. L., \& Chen, J. A. (2017). Reconceptualizing the sources of teaching self-efficacy: A critical review of emerging literature. Educational Psychology Review, 29(4), 795-833. https://doi.org/10.1007/s10648-016-9378-y

Muijs, D., \& Harris, A. (2003). Teacher leadership - Improvement through empowerment? An overview of the literature. Educational Management Administration and Leadership, 31, 437-448. https://doi.org/10.1177/0263211X030314007

Nespor, J. (1987). The role of beliefs in the practice of teaching. Journal of Curriculum Studies, 19, 317-328. https://doi.org/10.1080/0022027870190403

Pajares, M. F. (1992). Teachers' beliefs and educational research: Cleaning up a messy construct. Review of Educational Research, 62, 307-332. https://doi.org/10.3102/00346543062003307

Philippou, G. N., \& Christou, C. (1998). The effects of a preparatory mathematics program in changing prospective teachers' attitudes towards mathematics. Educational Studies in Mathematics, 35(2), 189-206. https://doi.org/10.1023/A:1003030211453

Poulson, L., Avramidis, E., Fox, R., Medwell, J., \& Wray, D. (2001). The theoretical beliefs of effective teachers of literacy in primary schools: An exploratory study of orientations to reading and writing. Research Papers in Education, 16(3), 271-292. https://doi.org/10.1080/02671520126827 
Richards, J. C. (2005). Professional development for language teachers: Strategies for teacher learning. New York, NY: Cambridge University Press. https://doi.org/10.1017/CBO9780511667237

Richardson, V. (1996). The role of attitudes and beliefs in learning to teach. In J. Sikula, T. J. Buttery \& E. Guyton (Eds.), Handbook of research on teacher education (2nd ed., pp. 102-119). New York: Simon \& Schuster Macmillan.

Richardson, V. (2003). The dilemmas of professional development. Phi Delta Kappan, 84(5), 401-406. https://doi.org/10.1177/003172170308400515

Schunk, D. H., Meece, J. R., \& Pintrich, P. R. (2014). Motivation in education: Theory, research, and applications (4th ed.). Boston, MA: Pearson.

Sendan, F., \& Roberts, J. (1998). Orhan: A case study in the development of a student teacher's personal theories. Teachers and Teaching, 4(2), 229-244. https://doi.org/10.1080/1354060980040203

Shang, H. F. (2010). Reading strategy use, self-efficacy and EFL reading comprehension. Asian EFL Journal, 12(2), $18-42$.

Sheu, P. H. (2015). Examining university students' motivation and their motivational behaviors in English learning with Structural Equation Modeling. International Journal of Humanities and Social Science, 5(8), 21-29.

Sheu, P. H. (2016). A correlation analysis of Taiwanese university students' motivations and their motivational behaviors. Journal of Education and Human Development, 5(2), 131-138. https://doi.org/10.15640/jehd.v5n2a16

Sheu, P. H. (2017). Examining the relationship of motivation, attitude, anxiety and achievement in English learning among elementary school students in Taiwan. International Journal of Language and Literature, 5(2), 174-184. https://doi.org/10.15640/ij1l.v5n2a18

Sparks, D., \& Loucks-Horsley, S. (1990). Five models of staff development. Oxford, OH: National Staff Development Council.

Stipek, D. J., Givvin, K. B., Salmon, J. M., \& MacGyvers, V. L. (2001). Teachers' beliefs and practices related to mathematics instruction. Teaching and Teacher Education, 17(2), 213-226. https://doi.org/10.1016/S0742-051X(00)00052-4

Tabachnick, B. R., \& Zeichner, K. M. (1985). The development of teacher perspectives: Final report. Madison, WI: Wisconsin Center for Education Research.

Tanaka, K., \& Ellis, R. (2003). Study abroad, language proficiency, and learner beliefs about language learning. JALT Journal, 25, 63-85.

Tercanlioglu, L. (2001). Pre-service EFL teachers' beliefs about foreign language learning and how they relate to gender. Journal of Research in Educational Psychology, 5(3), 145-162.

Thomas, J., \& Pedersen, J. E. (2001). When do science teachers learn to teach? In a comparison of school children's and pre-service teachers'science teacher illustrations. A paper presented at the Association for the Education of Teachers of Science annual meeting, Costa Mesa.

Tilfarlioglu, F., \& Cgnkara, E. (2009). Self-efficacy in EFL: Differences among proficiency groups and relationship with success. Novitas-ROYAL, 3(2), 129-142.

Tschannen-Moran, M., \& Hoy, A. W. (2001). Teacher efficacy: Capturing an elusive construct. Teaching and Teacher Education, 17(7), 783-805. https://doi.org/10.1016/S0742-051X(01)00036-1

Tschannen-Moran, M., Woolfolk Hoy, A., \& Hoy, W. K. (1998). Teacher efficacy: Its meaning and measure. Review of Educational Research, 68, 202-248. https://doi.org/10.3102/00346543068002202

Ushioda, E. (2008). Motivation and good language learners. In C. Griffiths (Ed.), Lessons from good language learners (pp.19-34). Cambridge, UK: Cambridge University Press. https://doi.org/10.1017/CBO9780511497667.004

Verloop, N. J., Driel, V., \& Meijer, P. C. (2001). Teacher knowledge and the knowledge base of teaching. International Journal of Educational Research, 35(5), 441-461. https://doi.org/10.1016/S0883-0355(02)00003-4 
Wenden, A. (1999). Commentary: An introduction to metacognitive knowledge and beliefs in language learning: Beyond the basics. System, 27(4), 435-441. https://doi.org/10.1016/S0346-251X(99)00043-3

Wesely, P. M. (2009). The language learning motivation of early adolescent French immersion graduates. Foreign Language Annals, 42, 270-286. https://doi.org/10.1111/j.1944-9720.2009.01021.x

Wigfield, A., \& Guthrie, J. (1997). Relations of children's motivation for reading to the amount and breadth of their reading. Journal of Educational Psychology, 89(3), 420-432. https://doi.org/10.1037/0022-0663.89.3.420

Woolfolk, H. A., Davis, H., \& Pape, S. J. (2006). Teacher knowledge and beliefs. In P. A. Alexander \& P. H. Winne (Eds.), Handbook of educational psychology (pp. 715-737). Mahwah, NJ: Lawrence Erlbaum.

Yashima, T. (2002). Willingness to communicate in a second language: The Japanese context. The Modern Language Journal, 86(1), 54-66. https://doi.org/10.1111/1540-4781.00136

Zheng, H. (2009). A review of research on EFL pre-service teachers' beliefs and practices. Journal of Cambridge Studies, 4(1), 73-81. 